\title{
Relationship of oestrus synchronization method, circulating hormones, luteinizing hormone and prostaglandin F-2 $\alpha$ receptors and luteal progesterone concentration to premature luteal regression in superovulated sheep
}

\author{
M. C. Schiewe ${ }^{1}$, T. A. Fitz ${ }^{2}$, J. L. Brown ${ }^{2}$, L. D. Stuart ${ }^{3}$ and D. E. Wildt ${ }^{1}$
}

${ }^{1}$ National Zoological Park, Smithsonian Institution, Washington, DC 20008, USA; ${ }^{2}$ Uniformed Services University of the Health Sciences, Bethesda, MD 20814, USA; and ${ }^{3}$ Veterinary Resources

Program, National Center for Research Resources, National Institutes of Health, Bethesda, MD 20892, USA

\begin{abstract}
Summary. Ewes were treated with exogenous follicle-stimulating hormone (FSH) and oestrus was synchronized using either a dual prostaglandin F-2 $\alpha$ (PGF-2 $\alpha$ ) injection regimen or pessaries impregnated with medroxy progesterone acetate (MAP). Natural cycling ewes served as controls. After oestrus or AI (Day 0), corpora lutea (CL) were enucleated surgically from the left and right ovaries on Days 3 and 6, respectively. The incidence of premature luteolysis was related $(P<0.05)$ to PGF-2 $\alpha$ treatment and occurred in 7 of 8 ewes compared with 0 of 4 controls and 1 of 8 MAP-exposed females. Sheep with regressing CL had lower circulating and intraluteal progesterone concentrations and fewer total and small dissociated luteal cells on Day 3 than gonadotrophin-treated counterparts with normal CL. Progesterone concentration in the serum and luteal tissue was higher $(P<0 \cdot 05)$ in gonadotrophin-treated ewes with normal $\mathrm{CL}$ than in the controls; but luteinizing hormone ( $\mathrm{LH})$ receptors/cell were not different on Days 3 and 6. There were no apparent differences in the temporal patterns of circulating oestradiol-17 $\beta$, FSH and LH. High progesterone in gonadotrophintreated ewes with normal CL coincided with an increase in total luteal mass and numbers of cells, which were primarily reflected in more small luteal cells than in control ewes. Gonadotrophin-treated ewes with regressing CL on Day 3 tended $(P<0 \cdot 10)$ to have fewer small luteal cells and fewer $(P<0.05)$ low-affinity PGF-2 $\alpha$ binding sites than sheep with normal CL. By Day 6, luteal integrity and cell viability was absent in ewes with prematurely regressed CL. These data demonstrate that (i) the incidence of premature luteal regression is highly correlated with the use of PGF-2 $\alpha$; (ii) this abnormal luteal tissue is functionally competent for 2-3 days after ovulation, but deteriorates rapidly thereafter and (iii) luteal-dysfunctioning ewes experience a reduction in numbers of small luteal cells without a significant change in luteal mass by Day 3 and, overall, have fewer low-affinity PGF- $2 \alpha$ binding sites.
\end{abstract}

Keywords: sheep; superovulation; premature luteal regression; prostaglandin F-2 $\alpha$; receptor

\section{Introduction}

Premature demise of the corpus luteum (CL) after exogenous hormone stimulation is a poorly understood cause of embryo recovery failure in goats and sheep (Armstrong et al., 1982, 1983a, b; Stubbing et al., 1986; Schiewe et al., 1990). Luteal dysfunction in these species generally is characterized by a transient rise and fall in circulating progesterone concentrations within 4 days of ovulation (Armstrong et al., 1982; Stubbing et al., 1986; Southee et al., 1988a). It remains 
unclear whether prematurely regressing CL have an inherently short lifespan caused by inadequate preovulatory follicular development, premature luteolysin release or hypersensitivity to luteolysis due to reduced luteotrophin stimulation.

Ovine CL consist of large and small steroidogenic cells which have been described morphometrically (Rodgers et al., 1984; Farin et al., 1986) and biochemically (Fitz et al., 1982; Hoyer \& Niswender, 1985; Balapure et al., 1989a). Large and small luteal cells are believed to develop from follicular granulosa and theca interna cells, respectively (McClellan et al., 1975; O'Shea et al., 1980). An increase in luteal weight throughout the oestrous cycle of naturally cycling ewes is characterized by hyperplasia of small luteal cells and hypertrophy of large cells (Farin et al., 1986). It appears that mean cell diameter and steroidogenesis stimulated by luteinizing hormone (LH) in small luteal cells are increased in cyclic ewes after superovulation (Hild-Petito et al., 1987). Small luteal cells contain most of the $\mathrm{LH}$ receptors (Fitz et al., 1982) and have low-affinity binding sites for prostaglandin F-2 $\alpha$ (PGF-2 $\alpha$ ) (Balapure et al., 1989a). Although LH binding to small luteal cells stimulates adenylate cyclase activity and increases steroidogenesis (Fitz et al., 1982; Rodgers et al., 1983; Hoyer \& Niswender et al., 1985; Harrison et al., 1987), the functional significance of low-affinity PGF- $2 \alpha$ receptors is unclear. These sites may play a complementary role in luteolysis to high-affinity PGF-2 $\alpha$ binding sites found on large luteal cells (Fitz et al., 1982; Balapure et al., 1989a) by binding excess PGF-2 $\alpha$ released by the uterus during the onset of luteal regression (McCracken et al., 1984).

This study characterized premature luteal regression (PLR) in gonadotrophin-treated ewes by examining periovulatory endocrine patterns and luteal tissue function during the early luteal phase. We were particularly interested in determining whether the type of oestrus synchronization method used with ovulation induction contributed to abnormal luteal integrity. This was studied by relating circulating concentrations of steroids and gonadotrophins, LH and PGF- $2 \alpha$ luteal cell receptor populations, luteal cell morphometrics and steroidogenesis to the occurrence of luteal dysfunction in oestrus-synchronized, superovulated sheep.

\title{
Materials and Methods
}

\begin{abstract}
Animals and facilities. Western crossbred, multiparous, white-faced ewes (2-5 years of age), Dorset breeding rams and a vasectomized Dorset teaser ram were housed in outdoor, partially sheltered pens $(6 \times 25 \mathrm{~m})$. All sheep were fed a hay-pelleted ration and lucerne roughage twice a day $(07: 00$ and 15:00 h) and provided free access to water. Indoor box stalls $(2.5 \times 2.5 \mathrm{~m})$ were used for isolating animals as needed.
\end{abstract}

Oestrus synchronization and ovulation induction. Sixteen females were either given a $6 \alpha-$ methyl-17 $\alpha$ acetoxyprogesterone-pessary (MAP, $60 \mathrm{mg}$ Depo-provera: Upjohn Co., Kalamazoo, MI, USA; 12-day insertion interval; $n=8$ ) or given PGF-2 $\alpha$ (Lutalyse ${ }^{\circledR}$ : Upjohn Co., $10 \mathrm{mg}, \mathrm{i} . \mathrm{m} ., 10$ days apart; $n=8$ ) oestrus synchronization treatment as described by Schiewe et al. (1990). Each female was given follicle-stimulating hormone pituitary extract (FSH-P) (Schering Veterinary Supplies, Kenilworth, NJ, USA) twice a day for 3 days (5, 4, 4, 3, 3 and 2 mg, respectively; i.m.) beginning $36 \mathrm{~h}$ before MAP removal or before the second PGF-2 $\alpha$ injection. Ewes were placed with one of 4 brisket-painted Dorset rams $36 \mathrm{~h}$ after MAP removal or PGF- $2 \alpha$ injection for natural mating and artificially inseminated $12 \mathrm{~h}$ later. Four naturally cycling ewes, not treated with hormones, mated by a vasectomized ram served as controls. Oestrous behaviour was monitored in all ewes for at least $30 \mathrm{~min}$ twice a day (07:00 and 18:00 h) by checking for mounting activity or painted wool on the female's rump.

Enucleation of luteal material and embryo collection. A laparoscopic examination was performed on Day $0,48-52 \mathrm{~h}$ after MAP removal or PGF-2 $\alpha$ (near the expected time of ovulation) to document ovarian activity and to perform insemination in utero (Schiewe et al., 1990), in addition to natural mating. Control ewes, which had a prerequisite of 1 ovulation per ovary, were subjected to laparoscopy and a sham-AI $24 \mathrm{~h}$ after the onset of a natural oestrus (also designated Day 0). On Days 3 and 6, each ewe was anaesthetized and subjected to laparotomy (Schiewe et al., 1990) to remove all luteal tissue from the left and right ovary, respectively. Enucleation sites were closed with suture. Enucleated CL from each donor were placed together in sterile Hank's Balanced Salt Solution (HBSS, Hanks \& Wallace, 1949) and stored at $4^{\circ} \mathrm{C}$ until prepared further for hormone receptor analysis. On Day 6, each uterine horn was exteriorized and flushed for embryos and ova (Schiewe et al., 1990).

Luteal tissue preparation. Within 1-3 h of removal from the ovary, the CL were weighed with an analytical balance (Mettler AE100, Fisher Co., Springfield, NJ, USA) using a weight extrapolation method. Each CL was sliced into 
0.5-mm sections using a Stadie-Riggs hand microtome (Thomas Scientific, Swedesboro, NJ, USA) and divided into 3 portions for separate analyses of LH and PGF-2 $\alpha$ receptors and progesterone concentration. Tissue designated for LH receptor and progesterone concentration analysis was placed in l-3-ml transport storage tubes (Fisher Co.), frozen directly in liquid $\mathrm{N}_{2}$ vapour and stored in liquid $\mathrm{N}_{2}$. The remaining luteal tissue, designated for PGF-2 $\alpha$ receptor analysis, was weighed and then processed to prepare suspensions of isolated cells (Balapure et al., 1989b). A suspension of single cells was prepared from the $0.5-\mathrm{mm}$ slices by dissociating tissue in $\mathrm{Ca}^{2+}$ - and $\mathrm{Mg}^{2+}-$ free $_{\mathrm{HBSS}}$ containing $2000 \mathrm{U}$ collagenase (Worthington Biochemical Corp., Halls-Mills, Freehold, NJ, USA)/g tissue per flask, $0.1 \%$ bovine serum albumin (BSA, Fraction V, Sigma Chemical Co., St Louis, MO, USA) and $0 \cdot 2 \%$ deoxyribonuclease (Sigma Chemical Co.). Luteal suspensions from Day-3 and Day-6 CL were incubated in a metabolic shaker bath at $37^{\circ} \mathrm{C}$ for 30 and $60 \mathrm{~min}$, respectively. Dissociated cells were washed twice in tissue culture medium 199 (TCM 199, Morton, 1970) using refrigerated $\left(4^{\circ} \mathrm{C}\right.$ ) centrifugation at $3000 \mathrm{~g}$ for $10 \mathrm{~min}$ to eliminate residual collagenase. The final cellular pellet was resuspended in TCM 199 containing $0.3 \%$ BSA ( $1 \mathrm{ml} / 25 \mathrm{mg}$ tissue). The preparation was stored overnight $\left(4^{\circ} \mathrm{C}\right)$ and then frozen within $12 \mathrm{~h}$ of processing. The number of viable cells produced in each cell suspension preparation was counted (expressed on a basis of $500 \mathrm{mg}$ luteal tissue) using a trypan blue stain and standard haemocytometer method immediately before freezing. The proportion of small (10-20 $\mu \mathrm{m}$ in diameter) and large ( $\geqslant 20 \mu \mathrm{m}$ in diameter) luteal cells in the tissue suspensions were assessed based on characteristic cellular differences determined by others (Rodgers \& O'Shea, 1982; Farin et al., 1986; Hild-Petito et al., 1987). Although some cells may have been damaged during dissociation (particularly large cells, which are more fragile; Braden et al., 1988), the procedures used for tissue dissociations and estimating numbers of cells were applied consistently throughout the project. Aliquants of cells were placed into cryovials in $0.5-\mathrm{ml} \mathrm{TCM} 199$ and then $0.5 \mathrm{ml}$ of $15 \%$ dimethyl sulphoxide (DMSO)-TCM 199 solution was added $\left(\right.$ at $\left.4^{\circ} \mathrm{C}\right)$ and allowed to equilibrate for $10 \mathrm{~min}$. Luteal cells were frozen in a programmable freezing unit by cooling at $4^{\circ} \mathrm{C} / \mathrm{min}$ to $-38^{\circ} \mathrm{C}$ and then $10^{\circ} \mathrm{C} / \mathrm{min}$ to $-100^{\circ} \mathrm{C}$ before storage in liquid $\mathrm{N}_{2}$.

Blood sampling and radioimmunoassays. Blood samples $(10 \mathrm{ml})$ were obtained by jugular venepuncture from all ewes beginning 1 day before gonadotrophin treatment or at the onset of detected oestrus for controls. Daily blood sampling (between 07:00 and 09:00 h) continued for 9-13 consecutive days. To characterize preovulatory oestradiolI7 $\beta$, FSH and LH dynamics in oestrus-synchronized animals, frequent blood samples were collected near the time of the anticipated preovulatory LH surge. To accommodate frequent blood sampling, ewes were moved from the outdoor pens to indoor-isolation stalls at the time of pessary removal or the PGF- $2 \alpha$ injection. An indwelling catheter with an obturator (Becton-Dickinson, Rutherford, NJ, USA) to prevent clotting was inserted into a jugular vein. Beginning $12 \mathrm{~h}$ after pessary removal or PGF-2 $\alpha$ injection, blood samples $(5 \mathrm{ml} / \mathrm{sample})$ were collected at intervals of $2 \mathrm{~h}$ for $24 \mathrm{~h}$. All blood samples were processed for serum collection and storage (Schiewe et al., 1990) and serum oestradiol-17 $\beta$, FSH, LH and progesterone concentrations were determined using specific radioimmunoassay (RIA) procedures. Because a previous study had detected no differences in oestradiol-17 $\beta$ concentrations in superovulated sheep with normal or abnormal luteal phases (Schiewe et al., 1990), this hormone was measured only during the $24 \mathrm{~h}$ serial bleeding window to characterize the preovulatory oestradiol surge.

Steroid concentrations were determined in unextracted sera using commercially available $\left[{ }^{125} \mathrm{I}\right]$ double-antibody RIA kits (Radioassays Systems Inc., Carson, CA, USA) as detailed and validated for sheep (Schiewe et al., 1990). The minimum detectable oestradiol-17ß concentration (i.e. assay sensitivity) was $3.5 \mathrm{pg} / \mathrm{ml}$ based on that at which $95 \%$ maximum binding occurrred $\left(\mathrm{ED}_{95}\right) ; 94 \cdot 3 \mathrm{pg}$ oestradiol- $17 \beta / \mathrm{ml}$ was needed to cause $50 \%$ binding inhibition ( $\mathrm{ED}_{50}$ ). The assay sensitivity for progesterone was $0.1 \mathrm{ng} / \mathrm{ml}$ and the $\mathrm{ED}_{50}$ was $4 \cdot 2 \mathrm{ng} / \mathrm{ml}$.

Serum LH and FSH were analysed by validated homologous double-antibody RIAs (Niswender et al., 1969; Brown et al., 1987). Purified ovine FSH (LER-1976-A2) and LH (LER-1374-A) were used as the labelled ligands and NIH-LH-S1 8 and NIH-FSH-S8 as the standards. Duplicate aliquants of serum $(100 \mu \mathrm{l})$ or standards $(0.03-4.0 \mathrm{ng}$ $\mathrm{LH} /$ tube; 1 $6-200 \mathrm{ng} \mathrm{FSH} /$ tube, respectively) were incubated at $4^{\circ} \mathrm{C}$ with first antibody for $48 \mathrm{~h}$ and then with labelled hormone for $24 \mathrm{~h}$. The second antibody was added $24 \mathrm{~h}$ after addition of labelled hormone (final volume $=500 \mu \mathrm{l}$ ) and incubated for an additional 3 days before $1 \mathrm{ml}$ of cold PBS was added and the antibody bound hormone was separated from free hormone by centrifugation $(2500 \mathrm{~g}$ for $30 \mathrm{~min})$. The $\mathrm{ED}_{50}$ values were 13 and $0.4 \mathrm{ng} / \mathrm{tube}$, and assay sensitivities were 10.9 and $0.5 \mathrm{ng} / \mathrm{ml}$ for $100 \mu \mathrm{l}$ serum for the LH and FSH assays, respectively. Intra- and interassay variability for all assays was $<10 \%$.

Progesterone content of luteal tissue. Progesterone content of luteal tissue was determined using the $\left[{ }^{125} \mathrm{I}\right] \mathrm{double}$ antibody RIA procedure described for serum (Schiewe et al., 1990). Wet weight of blot-dried tissue slices was determined using an analytical balance immediately before homogenization with a Polytron at medium speed using three 3-s pulses. To extract progesterone, homogenates were placed in $95 \%$ ethanol for $24 \mathrm{~h}$. The homogenate was then pelleted by centrifugation $(2500 \mathrm{~g}$ for $10 \mathrm{~min})$ and separated from the supernatant, which was maintained at $-20^{\circ} \mathrm{C}$. Before subsequent determination of progesterone content, a dried aliquant of the organic phase was reconstituted in assay buffer.

LH receptor and PGF-2a receptor analysis. $\mathrm{LH}$ receptors were assessed using a modification of the procedure described by Diekman et al. (1978). The number of receptors for LH was determined using Scatchard analysis of saturation curves. Thawed tissue slices were homogenized as described above and suspended in $25 \mathrm{~mm}$ Tris- $\mathrm{HCl}$ (pH 7.35) buffer containing $1 \mathrm{~mm}-\mathrm{CaCl}_{2}, 1 \mathrm{~mm}-\mathrm{NaN}_{3}$ and $0.1 \%$ gelatin $(1 \mathrm{ml} / 100 \mathrm{mg}$ wet weight tissue equivalents). Duplicate aliquants $(100 \mu \mathrm{l})$ of luteal tissue homogenates $\left(2 \mathrm{mg}\right.$ tissue weight) were incubated in Tris buffer with [ $\left.{ }^{125} \mathrm{I}\right]$ labelled human chorionic gonadotrophin (hCG) $(9.5 \mathrm{Ci} / \mathrm{mmol} ; 100 \mu \mathrm{l})$ ranging from 10000 to $2.1 \times 10^{6} \mathrm{c} . \mathrm{p} . \mathrm{m}$. in a 
final volume of $500 \mu \mathrm{l}$ to determine total binding. Parallel incubations of tubes containing nonradioactive hCG ( $1 \mu \mathrm{g}$ in $100 \mu \mathrm{l}$ HBSS; Sigma Chemical Co.) was used to determine the nonspecific binding. Samples were incubated in a metabolic shaker bath at $25^{\circ} \mathrm{C}$ for $16 \mathrm{~h}$. After incubation, $3 \mathrm{ml}$ of Tris buffer was added to all tubes containing tissue homogenates, the tubes were centrifuged at $7000 \mathrm{~g}\left(4^{\circ} \mathrm{C}\right)$ for $15 \mathrm{~min}$ and the supernatant was decanted. The radioactivity of each pellet was measured in a TM Analytic gamma counter having a $\left[{ }^{125} \mathrm{I}\right] \mathrm{detection}$ efficiency of $82 \%$. The $\mathrm{LH}$ receptor dissociation constant $\left(\mathrm{K}_{\mathrm{d}}\right)$ was $5.54 \pm 2.13 \times 10^{-11} \mathrm{M}$.

Prostaglandin F-2 $\alpha$ receptor analyses were performed with thawed, luteal cell preparations (Balapure et al., $1989 \mathrm{a}, \mathrm{b})$. Duplicate aliquants containing 50000 large luteal cells $(100 \mu \mathrm{l})$ were incubated with $50 \mathrm{nCi}\left[{ }^{3} \mathrm{H}\right] \mathrm{PGF}-2 \alpha$ $(195 \mathrm{Ci} / \mathrm{mmol} ; 100 \mu \mathrm{l})$ and one of 15 unlabelled PGF-2 $\alpha$ buffer concentrations $(0$ to $16 \mu \mathrm{M})$ in a total volume of $210 \mu \mathrm{l}$ HBSS-BSA buffer (pH 5.75) at $30^{\circ} \mathrm{C}$ for $45 \mathrm{~min}$ in a metabolic shaker bath. Ice-cold buffer (pH 7.35) containing $25 \mathrm{~mm}$ Tris, $1 \mathrm{~mm}-\mathrm{CaCl}_{2}$ and $0.1 \% \mathrm{BSA}$ (Tris-Ca-BSA) was added $(1.5 \mathrm{ml}$ ) to terminate incubation before applying the incubates to glass microfibre filters on a Yeda filtration manifold. The filters were washed twice with $1.5 \mathrm{ml}$ of Tris-Ca-BSA buffer, placed in vials containing $10 \mathrm{ml}$ scintillation fluid and equilibrated for $\sim 16 \mathrm{~h}$ at $4^{\circ} \mathrm{C}$. Bound radioactivity was determined using a Tracor Mark III liquid scintillation, beta counter having a $\left[{ }^{3} \mathrm{H}\right] \mathrm{detection}$ efficiency of $44 \%$. Binding data were converted to Scatchard plots using LIGAND (Munson \& Rodbard, 1980). The number of high- and low-affinity PGF- $2 \alpha$ receptors was quantitated by Scatchard analysis (binding affinity: $\mathrm{K}_{\mathrm{d}}=12.09 \pm 1.20 \mathrm{nM}$ and $\mathrm{K}_{\mathrm{d}}=870 \pm 160 \mu \mathrm{M}$, respectively).

Statistical analysis. A completely randomized design with an a priori arrangement of treatments was used to assess the periovulatory hormonal patterns and luteal characteristics of ewes synchronized into oestrus using MAP pessaries or PGF-2 $\alpha$. Analysis of variance (ANOVA) with a general linear model format was used to assess statistical variations in ovulation rate, luteal weight, luteal cell types, receptor populations and progesterone content of luteal cells. These analyses were facilitated by using a computerized software package (sYSTAT: Wilkinson, 1987). Differences among treatments were determined using Tukey's H.S.D. procedure (Snedecor \& Cochran, 1980). Pooled data involving the evaluation of ewes with normal luteal function versus those experiencing PLR were analysed using an independent Student's $t$ test (Snedecor \& Cochran, 1980). Temporal profiles and differences in hormone concentrations over time were evaluated using a 2-way ANOVA, repeated measures program. A hormonal surge was characterized as a profile in which the hormone concentration increased more than 3 standard deviations above basal concentrations. Results are expressed as means \pm standard error of the mean (s.e.m.).

\section{Results}

\section{Ovulation induction, luteal function and embryo recovery}

Superovulated ewes had more $(P<0.01) \mathrm{CL}$ than did spontaneously ovulating control ewes $(11.0 \pm 2.1$ vs. $2.0 \pm 0.0 \mathrm{CL})$. Mean luteal weight was greater $(P<0.05)$ on Day 3 in superovulated $(1 \cdot 0 \pm 0 \cdot 2 \mathrm{~g})$ than in control ewes $(0 \cdot 3 \pm 0 \cdot 1 \mathrm{~g})$. Two types of CL were observed: (i) 'normal CL', which on Days 3 and 6 were bright red and prominently raised above the ovarian surface and (ii) 'prematurely regressing CL', which were pale and pink to white. The differences in gross coloration between CL types were usually evident by Day 3. By Day 6, regressing CL lacked any distinct vascularity and were white (i.e. appearing as corpora albicans).

The incidence of PLR was related to treatment and occurred in none of the controls, 1 of 8 MAP-synchronized females and 7 of 8 ewes treated within PGF-2 $\alpha$. Because a higher $(P<0.05)$ proportion of ewes treated with PGF-2 $\alpha$ experienced early luteal regression, the mean total mass of luteal tissue/ovary on Day $6(0.5 \pm 0 \cdot 1 \mathrm{~g})$ was less $(P<0.05)$ than in the MAP-synchronized group $(2 \cdot 2 \pm 0 \cdot 5 \mathrm{~g})$.

On Day 3, CL undergoing premature luteolysis were no different in average weight from normal-appearing CL (Table 1). By Day 6, however, ewes with normal CL had a 5.4-times greater $(P<0.01)$ mean luteal mass than PLR ewes. Mean CL weight was similar among groups with normal-appearing CL (Table 1). Regardless of treatment, there was a highly positive correlation between number of $\mathrm{CL}$ and $\mathrm{CL}$ weight on Day $3(r=0.88, P<0.001)$ which was not evident on Day $6(r=0 \cdot 30, P>0 \cdot 10)$ because of rapidly declining $C L$ function in half the hormone-treated ewes. Embryos or ova were recovered from all donors with normal-appearing luteal tissue (mean $7 \cdot 7 \pm 2.2$ embryos/ewe); none was recovered from donors experiencing PLR.

\section{Temporal endocrine patterns}

Preovulatory oestradiol-17 $\beta$ surges were detected in 14 of 16 hormone-stimulated ewes, and there was no treatment effect $(P>0.05)$ on the magnitude or duration of the preovulatory 
Table 1. Influence of hormone treatment* and luteal condition on luteal tissue development in sheep. Number of corpora lutea $(C L)$ in parentheses

\begin{tabular}{|c|c|c|c|}
\hline \multirow{2}{*}{$\begin{array}{l}\text { Luteal } \\
\text { condition }^{2}\end{array}$} & \multirow{2}{*}{$\begin{array}{l}\text { No. of } \\
\text { ewes }\end{array}$} & \multicolumn{2}{|c|}{ Mean CL weight (mg) } \\
\hline & & Day 3 & Day 6 \\
\hline \multicolumn{4}{|c|}{ Normal luteal function } \\
\hline Control & 4 & $\begin{array}{c}305 \cdot 0 \pm 81 \cdot 7 \\
(n=4)\end{array}$ & $\begin{array}{c}525 \cdot 0 \pm 49 \cdot 8 \\
(n=4)\end{array}$ \\
\hline MAP/FSH-P & 7 & $\begin{array}{c}163 \cdot 6 \pm 22 \cdot 7 \\
(n=49)\end{array}$ & $\begin{array}{c}363 \cdot 2 \pm 45 \cdot 5 \\
(n=49)\end{array}$ \\
\hline PGF-2 $\alpha /$ FSH-P & 1 & $\begin{array}{c}550 \cdot 0 \\
(n=1)\end{array}$ & $\begin{array}{c}730 \cdot 0 \\
(n=1)\end{array}$ \\
\hline Overall mean & & $242 \cdot 9 \pm 44 \cdot 0^{b}$ & $450 \cdot 6 \pm 42 \cdot 7^{c}$ \\
\hline \multicolumn{4}{|c|}{ Premature luteal regression } \\
\hline MAP/FSH-P & 1 & $\begin{array}{c}133 \cdot 3 \pm 18 \cdot 7 \\
(n=3)\end{array}$ & $\begin{array}{c}33 \cdot 0 \pm 8 \cdot 3 \\
(n=3)\end{array}$ \\
\hline PGF-2 $\alpha /$ FSH-P & 7 & $\begin{array}{c}203 \cdot 9 \pm 40 \cdot 39 \\
(n=43)\end{array}$ & $\begin{array}{c}90 \cdot 4 \pm 15 \cdot 3 \\
(n=31)\end{array}$ \\
\hline Overall mean & & $228 \cdot 4 \pm 42 \cdot 7^{b}$ & $83 \cdot 7 \pm 14 \cdot 8^{d}$ \\
\hline
\end{tabular}

oestradiol-17 $\beta$ surge (Fig. 1). Generally, serum oestradiol-17 $\beta$ concentrations increased more than 8-10-fold from basal concentrations $(4-6 \mathrm{pg} / \mathrm{ml})$ to a peak of $59 \cdot 3 \pm 10.9 \mathrm{pg} / \mathrm{ml}$, which occurred by $20-36 \mathrm{~h}(25.4 \pm 1.5 \mathrm{~h}$; surge duration of $6-12 \mathrm{~h})$ after MAP removal or PGF-2 $\alpha$ injection. After ovulation, mean serum LH profiles were similar $(P>0 \cdot 10)$ in control and FSH-P-treated ewes (Fig. 1b, d). Likewise, there were no differences $(P>0 \cdot 10)$ in peripheral FSH or LH concentrations or temporal patterns within oestrus synchronization treatments. Regardless of whether FSH-Ptreated ewes eventually produced normal or regressed $\mathrm{CL}$, the FSH and $\mathrm{LH}$ patterns were similar $(P>0 \cdot 10$; Fig. 1d, f). Preovulatory FSH surges were detected in 13 of 16 hormone-treated ewes. Serum FSH patterns increased from a baseline of $50-100 \mathrm{ng} / \mathrm{ml}$ to a peak of $237.0 \pm 14.4 \mathrm{ng} / \mathrm{ml}$ (range $180-330 \mathrm{ng} / \mathrm{ml}$ ) which occurred $26 \cdot 5 \pm 1 \cdot 1 \mathrm{~h}$ after MAP removal or PGF-2 $\alpha$ injection. Across treatment groups, a preovulatory surge of LH was detected in 11 of 16 ewes and was sustained for $\sim 6-10 \mathrm{~h}$. Circulating $\mathrm{LH}$ increased from a baseline of $3-7 \mathrm{ng} / \mathrm{ml}$ to a peak of $72 \cdot 4 \pm 4.2 \mathrm{ng} / \mathrm{ml}$ (range $60-85 \mathrm{ng} / \mathrm{ml}$ ) which occurred $28 \cdot 8 \pm 1 \cdot 1 \mathrm{~h}$ after MAP removal or PGF-2 $\alpha$ injection. There was little fluctuation in circulating LH concentrations after ovulation (remaining $<10 \mathrm{ng} / \mathrm{ml})$ and no difference $(P>0 \cdot 10)$ among the control or oestrus synchronization treatment groups (Fig. 1b, d, f).

Compared with naturally cycling ewes, serum progesterone was detectable in FSH-P-treated ewes $48-72 \mathrm{~h}$ before controls. In sheep with normal $\mathrm{CL}$, mean circulating progesterone concentrations from Day 2 to Day 6 were higher $(P<0.05)$ than in controls with peak progesterone production $(4.3 \pm 0.6 \mathrm{ng} / \mathrm{ml})$ being an average of 3 times greater $(P<0.05 ;$ Fig. 1a, c). There was no apparent difference in the circulating progesterone pattern between MAP- and PGF- $2 \alpha-$ synchronized ewes within normal or regressing CL groups. The most marked difference was in the postovulatory progesterone profile for control and normal luteal function ewes compared with sheep undergoing early luteolysis (Fig. la, c, e). Although mean progesterone concentrations were higher $(P<0.05)$ on Day 2 in FSH-P-treated $(0.9 \pm 0.2 \mathrm{ng} / \mathrm{ml})$ than in control ewes $(0.2 \mathrm{ng} / \mathrm{ml})$, progesterone concentration steadily declined thereafter in sheep experiencing PLR (Fig. 1e). Mean circulating progesterone concentration in the latter ewes was not different $(P>0 \cdot 10)$ from controls on Day 3, but was reduced $(P<0.05)$ by Day 4 to basal levels $(\leqslant 0.2 \mathrm{ng} / \mathrm{ml})$. 


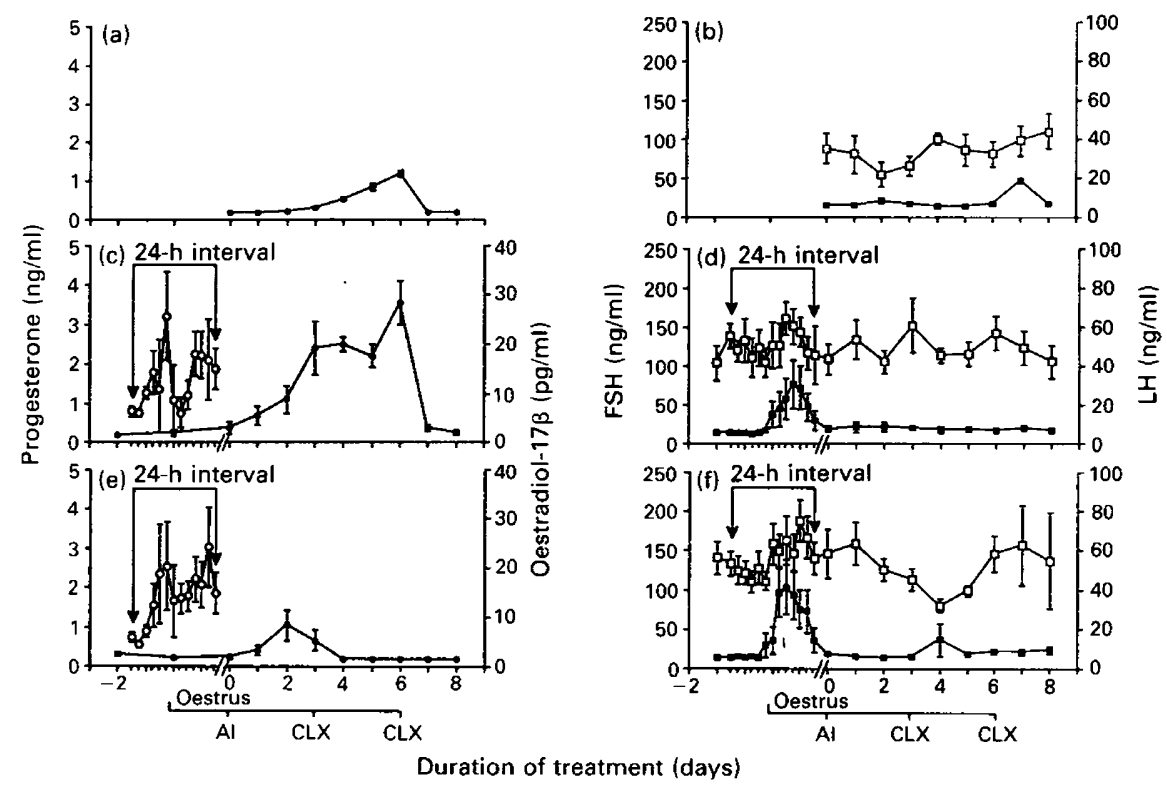

Fig. 1. Mean temporal oestradiol-17 $(O)$, progesterone $(\Theta)$, follicle-stimulating hormone $(\mathrm{FSH}, \square)$ and luteinizing hormone $(\mathrm{LH}, \mathbf{\square})$ profiles for controls $(a, b)$ and ewes treated with FSH pituitary extract (FSH P) with normal corpora lutea (CL), (c, d) or abnormal prematurely regressing $\mathrm{CL}(\mathrm{e}, \mathrm{f})$. Time of oestrus, artificial insemination (AI) and $\mathrm{CL}$ enucleation (CLX) are indicated.

Table 2. Influence of gonadotrophin treatment and corpora lutea $(C L)$ condition on numbers of small and large cells in ovine luteal tissue

\begin{tabular}{|c|c|c|c|c|c|c|c|}
\hline \multirow[b]{3}{*}{ Group } & \multirow{3}{*}{$\begin{array}{l}\text { No. of } \\
\text { ewes }\end{array}$} & \multicolumn{6}{|c|}{ Number of luteal cells $\left(\times 10^{-6}\right) / 500 \mathrm{mg}$ tissue } \\
\hline & & \multicolumn{3}{|c|}{ Day 3} & \multicolumn{3}{|c|}{ Day 6} \\
\hline & & Large & Small & Total & Large & Small & Total \\
\hline Control/sham & 4 & $2 \cdot 2 \pm 0 \cdot 4^{a}$ & $5 \cdot 1 \pm 2 \cdot 0^{\mathrm{a}}$ & $7 \cdot 2 \pm 1 \cdot 6^{\mathrm{a}}$ & $3.01 \pm 1 \cdot 1^{\mathrm{a}}$ & $9 \cdot 25 \pm 0 \cdot 8^{a}$ & $12 \cdot 3 \pm 0.4^{a}$ \\
\hline Normal CL & 8 & $4 \cdot 2 \pm 1 \cdot 5^{a}$ & $13 \cdot 5 \pm 3 \cdot 3^{b *}$ & $17 \cdot 8 \pm 4 \cdot 7^{a *}$ & $4 \cdot 38 \pm 1 \cdot 7^{\mathrm{a}}$ & $25 \cdot 69 \pm 5 \cdot 3^{b}$ & $30 \cdot 1 \pm 6 \cdot 7^{b}$ \\
\hline $\begin{array}{l}\text { Premature luteal } \\
\text { regression }\end{array}$ & 8 & $2 \cdot 9 \pm 1 \cdot 0^{\mathrm{a}}$ & $6.6 \pm 1.6^{\mathrm{ab}}$ & $9 \cdot 6 \pm 2 \cdot 4^{\mathrm{ab}}$ & ND & ND & ND \\
\hline
\end{tabular}

a,b Mean ( \pm s.e.m) column values with different superscripts differ $(P<0.05)$

*Excluding control ewes, a $t$-test comparison between ewes treated with follicle-stimulating hormone pituitary extract (normal CL vs. PLR) indicates differences $(P<0.05)$ in mean $( \pm$ s.e.m) column values.

$\mathrm{ND}=$ not detected.

Day $0=$ day of artificial insemination and onset of ovulation.

\section{Luteal integrity}

On Day 3, dissociates from control sheep and ewes with normal CL or PLR had similar numbers of large luteal cells (Table 2), but FSH-P-treated ewes with normal CL had more $(P<0.05)$ small and total luteal cells than controls or sheep with early regressing CL. On Day 6, luteal cells were so atrophied in the PLR group that quantitating large versus small cells was impossible. More $(P<0.05)$ small and total luteal cells (a $\sim 3$-fold increase) were observed on Day 6 in the gonadotrophin-treated ewes with normal CL than in controls. For both groups, the 
Table 3. Effect of luteal status and hormone treatment on the steroid concentration and receptor populations of luteal tissue in sheep

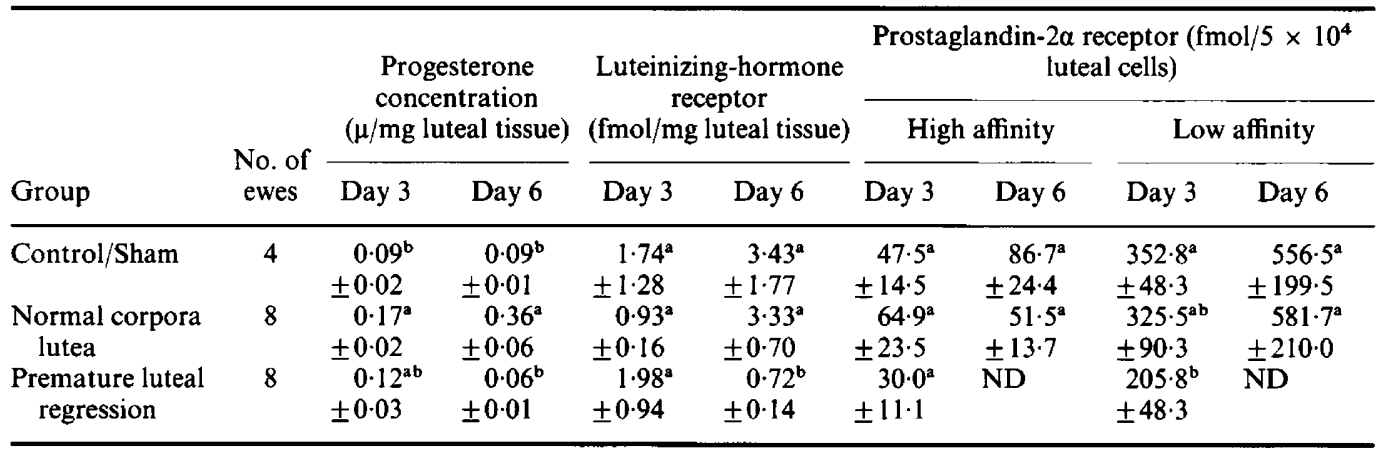

${ }^{\mathrm{a}, \mathrm{b}}$ Mean column values $( \pm$ s.e.m) with different superscripts differ $(P<0.05)$.

ND $=$ not detected.

Day $0=$ day of artificial insemination and onset of ovulation.

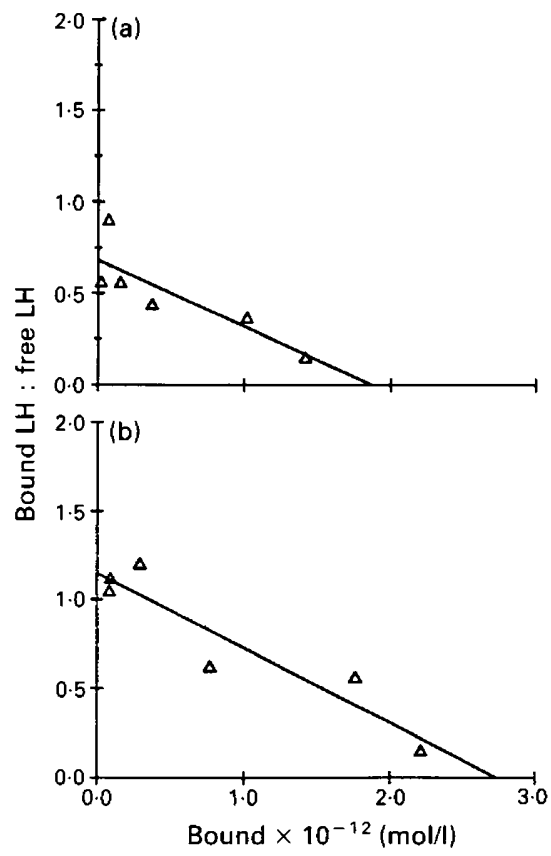

Fig. 2. Representative Scatchard analysis plots for luteinizing hormone (LH) receptor binding in (a) a control ewe and (b) a ewe treated with medroxyprogesterone acetate and folliclestimulating hormone pituitary extract and with normal corpora lutea on Day 6.

number of large cells remained constant between Days 3 and 6, but the number of small cells increased $(P<0.05)$ by $\sim 1.7$ times.

FSH-P-treated ewes with normal CL had more progesterone/mg of luteal tissue than control sheep on Days 3 and 6 and females experiencing PLR on Day 6 (Table 3). It appeared that progesterone secretion was compromised by $\sim 60 \mathrm{~h}$ after ovulation in ewes with short luteal phases. No differences $(P>0.05)$ were detected in numbers of LH receptors on Day 3 between normal and regressing CL groups (Table 3), but, by Day 6, the LH receptor population was 4-5 times higher $(P<0.05)$ in controls and ewes with normal CL than in those with PLR. Evaluation of PGF-2 $\alpha$ 


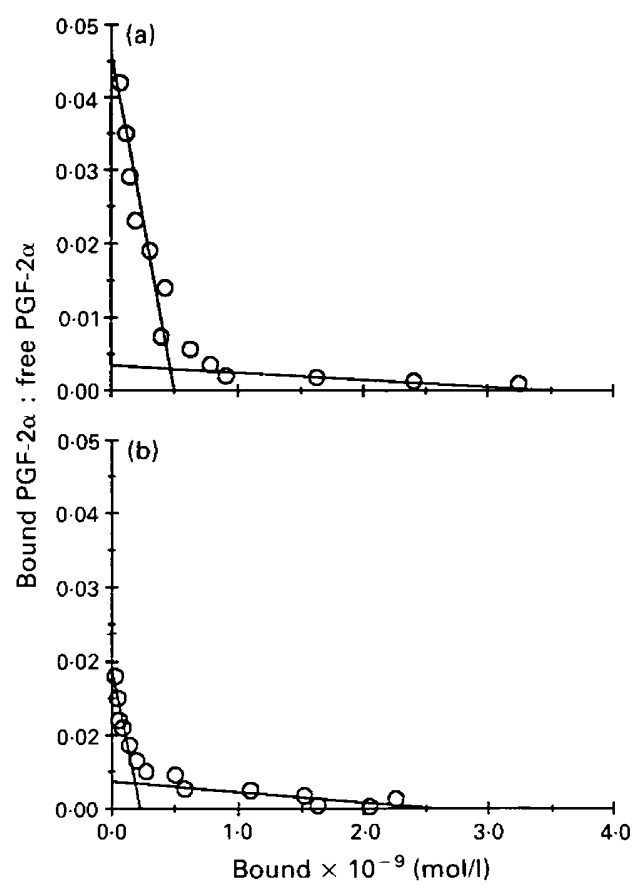

Fig. 3. Representative Scatchard analysis plots for prostaglandin F-2 $\alpha$ (PGF-2 $\alpha$ ) receptor binding for (a) a control ewe and (b) a ewe treated with medroxyprogesterone acetate and folliclestimulating hormone pituitary extract and with normal corpora lutea on Day 6 . The binding patterns revealed the presence of both high-affinity (almost vertical slope) and low-affinity (almost horizontal slope) binding sites.

receptors revealed no significant differences in the number of high-affinity receptors on Days 3 or 6 , although there tended $(P<0 \cdot 10)$ to be fewer on Day 3 in the PLR group than in ewes with normal CL. Numbers of low-affinity PGF-2 $\alpha$ receptors were not different $(P>0 \cdot 10)$ in controls and ewes with normal CL on Days 3 and 6 (Table 3). In contrast, fewer $(P<0.05)$ low-affinity PGF-2 $\alpha$ receptors were detected in sheep with regressing CL on Day 3 than in controls. Neither LH nor PGF-2 $\alpha$ receptor population affinities were influenced by exogenous hormone treatment, as demonstrated by the similarity of Scatchard analysis binding plots for representative naturally cycling or hormone-treated ewes (Figs 2 and 3, respectively).

\section{Discussion}

Using FSH-P with either an MAP or a PGF-2 $\alpha$ oestrus synchronization treatment produced multiple ovulations in sheep similar to our other recent findings (Schiewe et al., 1990). The present investigation affirmed that PGF-2 $\alpha$ oestrus synchronization was associated with a high incidence of PLR in FSH-treated sheep. Additionally, we compared FSH-P, pregnant mares' serum gonadotrophin (PMSG) and human menopausal gonadotrophin and determined that the premature demise of multiple CL was not associated with a specific gonadotrophin used (Schiewe et al., 1990). Luteal dysfunction was also observed in one of 5 natural cycling ewes given PGF-2 $\alpha$, but not in sheep pretreated with MAP pessaries (Schiewe et al., 1990). In agreement with our earlier investigation, no embryos were recovered from ewes with regressed CL.

Luteal dysfunction has been observed frequently in goats treated with PMSG or PGF-2 $\alpha$ (Armstrong et al., 1983b; Stubbing et al., 1986). In our study, circulating progesterone profiles 
clearly indicated that premature CL demise in gonadotrophin-treated ewes occurred 2-3 days after ovulation, which was similar to endocrine results in hormone-treated goats (Armstrong et al., 1983b). Findings of early luteal regression were also similar to those observed in anoestrous ewes induced to ovulate with GnRH (McLeod et al., 1982; McLeod \& Haresign, 1984; Hunter et al., 1988; Southee et al., 1988a) or by ram exposure (Oldham \& Martin, 1978; Oldham et al., 1985; Pearce et al., 1987).

Luteal development depends on major cellular transformations in the postovulatory follicle; therefore, the factors normally influencing follicular maturation (i.e. numbers of granulosa cells and gonadotrophin receptors) may contribute to luteal competence (Armstrong et al., 1982). Preovulatory progesterone priming appears critical to normal luteal development in sheep, especially in previously acyclic ewes (McLeod \& Haresign, 1984; Pearce et al., 1985; Southee et al., 1988a). An intriguing, yet confounding, factor in our study was that ewes were under the influence of endogenous progesterone immediately before PGF-2 $\alpha$. Despite this 'priming' effect, a high incidence of PLR occurred. It is possible that a critical duration (i.e. days) of progesterone priming of follicular maturation was not achieved using the double PGF-2 $\alpha$ injection, oestrus synchronization approach. Conversely, preovulatory MAP treatment may have allowed sufficient time for follicular cells to acquire the maturity needed for optimal luteinization and functional development (Armstrong et al., 1982). Progestogen priming before ovulation induction eliminates premature luteolysis in anoestrous ewes (McLeod \& Haresign, 1984; Oldham et al., 1985; Southee et al., 1988a). Interestingly, the common occurrence of premature luteolysis in PGF-2 $\alpha$-treated ewes could not be attributed to differences in temporal hormonal profiles during the periovulatory period. This suggests two possibilities. First, the similarity in preovulatory gonadotrophin and oestradiol-17 $\beta$ profiles may indicate that folliculogenic events are not associated with premature $\mathrm{CL}$ demise. Alternatively, circulating hormones may be inadequate markers for these events or the blood sampling protocol used may not have been sufficiently rigorous to detect subtle endocrine differences between animal groups.

The increased total luteal weight observed in gonadotrophin-treated ewes with normal CL, compared with controls, was due mostly to an increased population of small luteal cells. Corpora lutea from ewes undergoing premature luteolysis were already experiencing a sharp reduction in both large and small luteal cells by Day 3, but the primary loss was of the smaller cells. Although total luteal mass was greater in sheep with regressing CL than in controls, these CL did not produce more small luteal cells or progesterone (in circulation or in tissue). Since LH-stimulated progesterone production by small luteal cells increases significantly in ewes injected with PMSG (Hild-Petito et al., 1987), it is likely that the increased serum progesterone concentrations and progesterone content/mg luteal tissue in gonadotrophin-treated sheep was due to more small cells and enhanced steroidogenesis. The improved steroidogenic potential of the small luteal cells, however, could not be attributed to increased LH binding, because the number of $\mathrm{LH}$ receptors/mg tissue was no different among groups. A recent study of short-lived CL in post-partum ewes (Braden et al., 1989) has also determined that the reduced steroidogenic competence of luteal cells is not caused by changes in numbers of $\mathrm{LH}$ receptors. Therefore, the decline in progesterone production by Day 3 in gonadotrophin-treated ewes with regressing CL was probably due to a reduced steroidogenic population of small luteal cells and/or insensitivity to luteotrophic stimuli.

The rapid loss of luteal integrity during short luteal phases was similar to the normal demise of CL caused by increased pulsatile release of PGF-2 $\alpha$ from the uterus (McCracken et al., 1984). The occurrence of PLR at $\sim$ Day 4 after the LH surge was consistent with the time when natural cyclic ewes are susceptible to exogenous prostaglandin-induced luteolysis (Acritopoulou \& Haresign, 1980). Several studies indicate that some factor of uterine origin (probably PGF-2 $\alpha$ ) is responsible for PLR (Lewis \& Bolt, 1987; Copelin et al., 1987; Southee et al., 1988b). It also could be due to increased sensitivity of the CL to tonic secretion of a luteolysin (Braden et al., 1989). In the latter study, early luteolysis during the post-partum period could not be attributed to increased numbers of prostaglandin receptors or binding affinity to PGF- $2 \alpha$ by the large luteal cells. In the present 
study, we identified 2 types of PGF-2 $\alpha$ binding sites (high and low affinity), which verified other recent reports (Balapure et al., 1989a, b). Differences in numbers of PGF-2 $\alpha$ receptors and luteal cells were not detected between control and gonadotrophin-treated ewes producing normal luteal tissue, but ewes experiencing premature luteolysis had fewer low-affinity PGF-2 $\alpha$ receptors (Day 3), which are the binding sites located predominantly on small luteal cells (Balapure et al., 1989a). A relationship may exist between the number of low-affinity PGF-2 $\alpha$ receptors on small luteal cells and luteal competence. It is also possible that the low-affinity PGF-2 $\alpha$ binding site has a high affinity for some other eicosanoid, perhaps a luteotrophin such as PGE $_{2}$ (Balapure et al., 1989a). In our study, the onset of premature luteal demise occurred when large luteal cells acquired highaffinity PGF-2 $\alpha$ binding sites (Fitz et al., 1982). The tendency for fewer high-affinity receptors in sheep with abnormal CL may indicate increased occupancy of PGF-2 $\alpha$ at the binding site. If so, the potential hypersensitivity of these CL to the luteolysin may have been masked by the PGF- $2 \alpha$ receptor downregulation. It is interesting that dissociates from CL destined for early regression contained fewer small, but not large, cells. A preferential loss of small luteal cells during luteolysis was reported in morphometric analyses of ovine luteal slices (Braden et al., 1988) and dissociates (Schwall et al., 1986). The reduced abundance of small cells during luteolysis as well as in CL destined for premature involution implies that the 2 processes may be related, and that the small cells (or their paucity) may play a role in both processes.

Although effective for inducing luteolysis and oestrus in ewes, the influence of PGF- $2 \alpha$ on subsequent luteal development must be considered critically. Our data suggest that, under the conditions described, exogenous PGF- $2 \alpha$ is contraindicated because of an increased incidence of PLR. Hypotheses that the cause of early luteolysis was associated with abnormal preovulatory endocrine events and/or inadequate follicular maturation were not substantiated by these or other recent results from our laboratory (Schiewe et al., 1990). The latter study determined that numbers of antral follicles and time of ovulation did not differ in gonadotrophin-treated ewes with normal or regressed CL. The cause of luteal dysfunction remains unknown. However, changes in the number of small luteal cells and low-affinity PGF-2 $\alpha$ binding sites in the periovulatory period may be responsible for the transient normality of CL function. Additional studies are necessary to determine the influence of PGF-2 $\alpha$ on development, maturation and transformation of follicular theca and granulosa cells to luteal cells. Our understanding of the cause of PLR may be improved if we can resolve how progestogen pretreatment inhibits the abnormal physiological changes associated with early luteolysis.

The authors thank Drs D. Bolt and C. E. Rexroad, Jr of the USDA Animal Reproduction Laboratory for assistance and Mr J. Poole, R. Axeline and other animal keepers of the Ungulate Unit, National Institutes of Health Animal Center for their cooperation. Special thanks are expressed to Dr W. Ji of the Kunming Institute of Zoology, Republic of China, for his assistance during the surgical and bleeding phases of this project. This research was supported, in part, by grants to M. C. Schiewe, T. A. Fitz and J. L. Brown from U.S.U.H.S. (No. TO8527, CO8517 and CO8527, respectively) and to D. E. Wildt from the Friends of the National Zoo and Women's Committee of the Smithsonian Associates. The opinions and assertions contained herein are those of the authors and are not to be construed as representing those of the U.S.U.H.S. or the Department of Defense.

\section{References}

Acritopoulou, S.W. \& Haresign, J.P. (1980) Response of ewes to a single injection and an analogue of PGF- $2 \alpha$ given at different stages of the oestrous cycle. $J$. Reprod. Fert. 58, 219-223.

Armstrong, D.T., Pfitzner, A.P., Porter, K.J., Warnes, G.M., Janson, P.O. \& Seamark, R.F. (1982) Ovarian responses of anoestrous goats to stimulation with pregnant mare serum gonadotrophin. Anim. Reprod. Sci. 5, 15-23.

Armstrong, D.T., Pfitzner, A.P., Warnes, G.M. \& Seamark, R.F. (1983a) Superovulation treatments and embryo transfer in Angora goats. J. Reprod. Fert. 67, 403-410. 
Armstrong, D.T., Pfitzner, A.P., Warnes, G.M., Ralph, M.M. \& Seamark, R.F. (1983b) Endocrine responses of goats after induction of superovulation with PMSG and FSH. J. Reprod. Fert. 67, 395-401.

Balapure, A.K., Caicedo, I.C., Kawada, K., Watt, D.S., Rexroad, C.E., Jr \& Fitz, T.A. (1989a) Multiple classes of prostaglandin $\mathrm{F}-2 \alpha$ binding sites in subpopulations of ovine luteal cells. Biol. Reprod. 41, 385-392.

Balapure, A.K., Rexroad, C.E., Jr, Kawada, K., Watt, D.S. \& Fitz, T.A. (1989b) Structural requirements for prostaglandin analog interaction with the ovine corpus luteum PGF- $2 \alpha$ receptor. Implications for development of a photoaffinity probe. Biochem. Pharmacol. 14, 2375-2381.

Braden, T.D., Gamboni, F. \& Niswender, G.D. (1988) Effects of prostaglandin F-2 $\alpha$-induced luteolysis on the population of cells in the ovine corpus luteum. Biol. Reprod. 39, 245-253.

Braden, T.D., Sawyer, H.R. \& Niswender, G.D. (1989) Functional and morphological characteristics of the first corpus luteum formed after parturition in ewes. J. Reprod. Fert. 86, 525-533.

Brown, J.L., Stuart, L.D. \& Chakaraborty, P.K. (1987) Endocrine profiles, testicular gonadotropin receptors and sperm production in hemi-castrated ram lambs. J. Anim. Sci. 65, 1563-1570.

Copelin, J.P., Smith, M.F, Garverick, H.A. \& Youngquist, R.S. (1987) Effect of the uterus on subnormal luteal function in anestrous beef cows. J. Anim. Sci. 64, 1506-1511.

Diekman, M.A., O'Callaghan, P., Nett, T.M. \& Niswender, G.D. (1978) Validation of methods and quantification of receptors for $\mathrm{LH}$ throughout the estrous cycle and early pregnancy in ewes. Biol. Reprod. 19, 999-1009.

Farin, C.E., Moeller, C.L., Sawyer, H.R., Gamboni, F. \& Niswender, G.D. (1986) Morphometric analysis of cell types in the ovine corpus luteum throughout the estrous cycle. Biol. Reprod. 35, 1299-1308.

Fitz, T.A., Mayan, M.H., Sawyer, H.R. \& Niswender, G. D. (1982) Characterization of two steroidogenic cell types in the ovine corpus luteum. Biol. Reprod. 27, 703-711.

Hanks, J.H. \& Wallace, R.D. (1949) Relation of oxygen and temperature in the preservation of tissues by refrigeration. Proc. Soc. Exp. Biol. Med. 71, 196-200.

Harrison, L.M., Kenny, N. \& Niswender, G.D. (1987) Progesterone production, LH receptors and oxytocin secretion by ovine luteal cell types on Days 6, 10 and 15 of the oestrous cycle and Day 25 of pregnancy. $J$. Reprod. Fert. 79, 539-548.

Hild-Petito, S., Ottobre, A.C. \& Hoyer, P.B. (1987) Comparison of subpopulations of luteal cells obtained from cyclic and superovulated ewes. $J$. Reprod. Fert. 80, 537-544.

Hoyer, P.B. \& Niswender, G.D. (1985) The regulation of steroidogenesis is different in the two types of ovine luteal cells. Can. J. Physiol. Pharmacol. 63, 240-248.

Hunter, M.G., Southee, J.A. \& Lamming, G.E. (1988) Function of abnormal corpora lutea in vitro after GnRH-induced ovulation in the anoestrous ewe. $J$. Reprod. Fert. 84, 139-148.

Lewis, G.S. \& Bolt, D.J. (1987) Effects of suckling, progestogen-impregnated pessaries or hysterectomy on ovarian function in autumn-lambing postpartum ewes. J. Anim. Sci. 64, $216-225$.

McClellan, M.C., Diekman, M.A., Abel, J.H., Jr. \& Niswender, G.D. (1975) LH, progesterone and the morphological development of normal and superovulated corpora lutea in sheep. Cell Tiss. Res. 164, 291-307.

McCracken, J.A., Schramm, W. \& Okulicz, W.C. (1984) Hormone receptor control of pulsatile secretion of PGF-2 $\alpha$ from the ovine uterus during luteolysis and its abrogation in early pregnancy. Anim. Reprod. Sci. $7,3 \mathrm{I}-55$.

McLeod, B.J. \& Haresign, W. (1984) Evidence that progesterone may influence subsequent luteal function in the ewe by modulating preovulatory follicle development. J. Reprod. Fert. 71, 381-386.

McLeod, B.J., Haresign, W. \& Lamming, G.E. (1982) Response of seasonally anoestrous ewes to smalldose multiple injections of Gn-RH with and without progesterone pretreatment. J. Reprod. Fert. 65, 223-230.

Morton, H.C. (1970) A survey of commercially available tissue culture media. In Vitro 6, 89-108.

Munson, P.J. \& Rodbard, D. (1980) LIGAND: A versatile computerized approach for characterization of ligand-binding systems. Anal. Biochem. 107, 220-239.

Niswender, G.D., Reichert, L.E., Jr, Midgley, A.R. \& Nalbandov, A.V. (1969) Radioimmunoassays for bovine and ovine luteinizing hormone. Endocrinology 84, 1166-1173.

Oldham, C.M. \& Martin, G.B. (1978) Stimulation of seasonally anovular Merino ewes by rams. II. Premature regression of ram-induced corpora lutea. Anim. Reprod. Sci. 1, 291-295.

Oldham, C.M., Pearce, D.T. \& Gray, S.J. (1985) Progesterone priming and age of ewe affect the life span of corpora lutea induced in the seasonally anovulatory Merino ewe by the 'ram effect'. $J$. Reprod. Fert. 75, 29-33.

O'Shea, J.D., Cran, D.G. \& Hay, M.F. (1980) Fate of the theca interna following ovulation in the ewe. Cell Tiss. Res. 210, 305-319.

Pearce, D.T., Martin, G.B. \& Pearce, C.M. (1985) Corpora lutea with a short life-span induced by rams in seasonally anovulatory ewes are prevented by progesterone delaying the preovulatory surge of LH. $J$. Reprod. Fert. 75, 79-85.

Pearce, D.T., Oldham, C.M., Haresign, W. \& Gray, S.J. (1987) Effects of duration and timing of progesterone priming on the incidence of corpora lutea with a normal life-span in Merino ewes induced to ovulate by the introduction of rams. Anim. Reprod. Sci. 13, 81-89.

Rodgers, R.J. \& O'Shea, J.D. (1982) Purification, morphology and progesterone content of three cell types isolated from the corpus luteum of the sheep. Aust. $J$. Biol. Sci. 35, 441-455.

Rodgers, R.J., O'Shea, J.D. \& Findlay, J.K. (1983) Progesterone production in vitro by small and large ovine luteal cells. J. Reprod. Fert. 69, 113-124.

Rodgers, R.J., O'Shea, J.D. \& Bruce, N.W. (1984) Morphometric analysis of the cellular composition of the ovine corpus luteum. J. Anat. 138, 757-769.

Schiewe, M.C., Howard, J.G., Goodrowe, K.L., Stuart, L.D. \& Wildt, D.E. (1990) Human menopausal 
gonadotrophin (hMG) induces ovulation in sheep, but embryo recovery after PGF- $2 \alpha$-synchronization is compromised by premature luteal regression. Theriogenology 34, 469-486.

Schwall, R.H., Gamboni, F., Mayan, M.H. \& Niswender, G.D. (1986) Changes in the distribution of sizes of ovine luteal cells during the estrous cycle. Biol. Reprod. 34, 911-918.

Snedecor, G.W. \& Cochran, W.G. (1980) Statistical Methods. Iowa State University Press, Ames, IA.

Southee, J.A., Hunter, M.G., Law, A.S. \& Haresign, W. (1988a) Function of abnormal corpora lutea in vivo after GnRH-induced ovulation in the anoestrous ewe. J. Reprod. Fert. 84, 131-137.
Southee, J.A., Hunter, M.G., Law, A.S. \& Haresign, W. (1988b) Effect of hysterectomy on the short life-cycle corpus luteum produced after GnRH-induced ovulation in the anoestrous ewe. J. Reprod. Fert. 84, 149-155.

Stubbing, R.B., Bosu, W.T.K., Barker, C.A.V. \& King, G.J. (1986) Serum progesterone concentrations associated with superovulation and premature corpus luteum failure in dairy goats. Can. J. Vet. Res. 50, 369-373.

Wilkinson, L. (1987) systaT: The System for Statistics. Systat, Inc. Evanston, IL.

Received 30 May 1990 